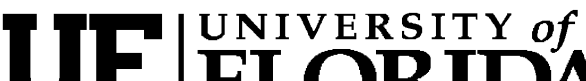 FLORIDA \\ IFAS Extension
}

\section{Silage Harvesting, Storing, and Feeding ${ }^{1}$}

\section{A. T. Adesogan and Y. C. Newman ${ }^{2}$}

Silage can be a convenient and economical feed for the cattle industry. Some producers routinely produce silage, but others only produce silage when field drying is difficult or impossible. Crops such as corn and sorghum are not ideal for hay production because they contain considerable moisture at the optimal harvest time, and their thick stalks delay drying. Warm-season grasses like bermudagrass and bahiagrass can be harvested as hay, but, in Florida, frequent rains often delay harvesting and curing and can lead to extensive losses of dry matter (DM) from the hay. Harvesting such grasses as silage may reduce harvesting losses and allow a more timely harvest, thereby improving forage quality.

Silage is high moisture forage, stored in the absence of oxygen and preserved by acids produced during the fermentation. During ensiling, bacteria ferment sugars in the plant to organic acids that lower the $\mathrm{pH}$ of the silage to levels that inhibit the growth of undesirable organisms. The silage remains preserved as long as air is kept out because spoilage-causing yeasts in silages remain dormant in the absence of oxygen. Entry of oxygen into the silo revives the yeasts and may cause spoilage.
This publication discusses the advantages, disadvantages and phases of silage fermentation and the factors affecting silage quality.

Properly made silage has several advantages over hay, including the following:

- Lower probability of weather-related damage or delays during harvest

- Lower field, harvest, and storage losses

- Greater flexibility and fit for many livestock feeding programs

Disadvantages include:

- Higher moisture content results in heavier forage that is less economic to haul

- Requires specialized equipment for harvesting, storing, and feeding operations

- High loss potential if silage is not made well

- Less marketable if the silage is not fed on the farm

1. This document is SS-AGR-177, one of a series of the Agronomy Department, Florida Cooperative Extension Service, Institute of Food and Agricultural Sciences, University of Florida. First Published July 2002. Revised April 2006 and September 2010. This publication is also part of the Florida Forage Handbook, an electronic publication of the Agronomy Department. For more information you may contact Yoana Newman (ycnew@ufl.edu). Please visit the EDIS Web site at http://edis.ifas.ufl.edu.

2. A. T. Adesogan, Associate Professor, Department of Animal Sciences; Y. C. Newman, Assistant Professor, Agronomy Department; Florida Cooperative Extension Service, Institute of Food and Agricultural Sciences, University of Florida, Gainesville, FL 32611.

The use of trade names in this publication is solely for the purpose of providing specific information. UF/IFAS does not guarantee or warranty the products named, and references to them in this publication does not signify our approval to the exclusion of other products of suitable composition. 
- Shorter shelf life after the silo is opened

\section{Crops for Silage}

Many crops grown in Florida can be preserved as silage or haylage (round-bale silage; discussed later). The type of livestock, available machinery, soil type, rainfall, availability of irrigation, and potential yield are important considerations in deciding which crops to plant and store as silage.

Corn silage is usually considered the best silage because of its high energy concentration, which can be used to optimize animal performance. The best time to harvest corn silage was previously thought to be when the grain is denting and the milk line has moved $1 / 2$ to $2 / 3$ of the way down the kernel (Table 1 ). However, the kernel milk line should no longer be the only index used to predict harvest dates. This index can give misleading predictions of optimal harvest time due to the presence of new attributes in modern corn hybrids like high stay-green. Decisions on time of harvest should be based on oven dry matter (DM) measurement, and corn should be harvested for silage when the DM concentration is between 30 and $35 \%$. Alternative, less accurate methods for measuring DM concentration include using a Koster moisture tester or a microwave oven.

Good silage can also be made from forage sorghum, sorghum-sudan hybrids, soybeans, and other warm-season annuals, but they are lower in energy than corn silage. Forage sorghum is usually direct cut, but the moisture content at optimal maturity for harvest is often too high for proper ensiling. Therefore, choose hybrids with low moisture ratings when possible, and aim to harvest when the DM concentration is $30-35 \%$.

Sorghum-sudan hybrids, soybeans, and cowpeas usually have high moisture concentrations at optimal maturities. Therefore, wilting is often needed to ensure good silage quality.

Excellent silage can also be made from cool-season annuals, such as small grain cereals and ryegrass when they are harvested at optimal maturities. Wilting is advisable if the DM at harvest is less than $30 \%$. Silage production from bermudagrass, stargrass, limpograss, perennial peanut, and alfalfa is also feasible. However, low sugar contents and high buffering capacities (resistance to change in $\mathrm{pH}$ ) make it more difficult to ensile these crops. Consequently, these crops should be wilted to 35 to $45 \%$ DM to concentrate the sugars they contain before they are ensiled.

\section{Phases of Silage Fermentation}

The ensiling process takes several days and can be divided into five phases. Each of the five phases is characterized by different changes in the forage.

- Phase 1: This phase begins from the time of harvesting the crop to the time oxygen is depleted from the sealed silo. Due to continued plant respiration, plant enzymes and aerobic bacteria cause nutrient losses by degrading plant proteins and converting sugars into carbon dioxide and water, and generating heat. The heat increases the silage temperature by 15 to $20^{\circ} \mathrm{F}$ or more, depending on the amount of air available. This phase progresses until the oxygen is depleted. It takes a few hours ideally but can last for up to 48 hours in poorly made silages. Harvesting at the correct plant maturity, chopping to the right particle length, packing the silo tightly, and sealing within 12 hours of harvesting are key to minimizing nutrient losses during this phase.

- Phase 2: This phase starts after the oxygen is used up, when anaerobic bacteria begin to ferment plant sugars into organic acids, alcohols, carbon dioxide, and nitrogenous compounds. The organic acids lower silage $\mathrm{pH}$ from above 6 to about 5. If silage $\mathrm{pH}$ drops slowly and the moisture concentration is high due to harvesting too early, clostridial bacteria may grow. These bacteria degrade sugars and convert lactic acid to butyric acid, releasing strong offensive odors. They also break down protein to nonprotein nitrogen and undesirable end products like amines. These changes lead to increased dry matter loss and reduced palatability and quality of the silage.

- Phase 3: Once the $\mathrm{pH}$ falls below 5, the lactic-acid-producing bacteria (LAB) dominate the fermentation and reduce the $\mathrm{pH}$ to about 4 or 4.5 in well-made silages and haylages (round-bale silage), respectively. Lactic acid is 
more effective than other organic acids at reducing the $\mathrm{pH}$. Therefore, $\mathrm{LAB}$ that ferment sugars to lactic acid alone (homolactic LAB) are more efficient at causing a fast $\mathrm{pH}$ drop and preserving nutrients than others (heterolactic LAB) that produce lactic acid and other products. This phase can last for three days to four weeks, and it ends when fermentable sugars are depleted. This phase is often limited in warm-season grasses and other forages with low sugar concentrations (less than 5-8\% of dry matter) because of inadequate amounts of sugars for the fermentation.

- Phase 4: Once the $\mathrm{pH}$ drops to or below 4.0 (4.5 in haylages), the silage becomes stable, and the growth of undesirable microbes is prevented. The quality of the silage can be maintained for the rest of the storage duration if the silo remains sealed, and air does not penetrate the silo.

- Phase 5: This phase begins after aerobic conditions are restored once the silo is opened during feedout. After air penetration occurs, yeasts and molds that were dormant during the fermentation are revived. These fungi use sugars, lactic acid, and other nutrients for growth and produce carbon dioxide and heat as byproducts. Excessive heat accumulation denatures proteins and other nutrients in the silage. Collectively, these changes increase DM losses and reduce silage quality. Molds on the silage may also produce mycotoxins that when consumed reduce animal performance and cause various diseases. To prevent these problems, excellent management is necessary, particularly in bunker or drive-over pile silos. The silage should be fed out at a rate of at least 8 to 12 inches per day, and a straight face should be maintained with shavers. Additives or inoculants that hinder the growth of spoilage yeasts and molds will increase bunk life and preserve the quality of the silage.

\section{Factors Affecting Silage Quality}

Several factors influence the fermentation, preservation, and quality of silage. These include sugar concentration, buffering capacity, DM concentration, chop length and fineness, temperature during ensiling and storage, rate of harvest, packing density, and air exposure during harvest, storage, and feeding.

\section{Sugar Concentration and Buffering}

Water-soluble carbohydrates (mostly sugars) are used up during plant respiration until the oxygen that remains in the forage mass is depleted. These sugars are the primary carbohydrates fermented to lactic and acetic acids by bacteria to produce a low $\mathrm{pH}$ and stable silage. In general, forages with less than 5-8\% water-soluble carbohydrates in the DM may not reach a $\mathrm{pH}$ low enough to produce stable, high-moisture silage. Corn, sorghum, sorghum-sudan hybrids, and cool-season annual grasses usually have sugar concentrations above 5\% dry matter (Table 1), and a good, stable silage is often achieved. Forage crops, such as warm-season perennial grasses and legumes, have low sugar concentrations, and the high protein concentration of legumes buffers (slows) the $\mathrm{pH}$ decline from 5.5 to 4.5 during ensiling.

Consequently, these forages are more difficult to ensile and should be wilted to 35 to $45 \%$ DM before ensiling, which can be challenging if bunkers are used. Additive or inoculant application may also aid the fermentation of such forages.

\section{Dry-Matter Concentration}

Harvesting should be planned for dry days because small amounts of rainfall can reduce silage quality. Forages that have excess $(>70 \%)$ or inadequate moisture $(<45 \%)$ may not ensile well for different reasons. Higher moisture concentrations can result in greater seepage losses and possible pollution of nearby water bodies. Such high-moisture silages are also more likely to undergo a clostridial fermentation, which leads to high DM losses, protein degradation, high butyric acid concentrations, and reduced palatability. Wilting high-moisture forage to at least $35 \%$ dry matter is a good practice that reduces clostridial fermentations. Wilting usually results in good silage particularly when sugar concentration is low, and buffering against $\mathrm{pH}$ decline is high. Wilting is usually necessary before ensiling bermudagrass, legumes, sorghum-sudan, and millet forages because these forages are often only 20 to $25 \%$ dry matter at the time of cutting. 
Forages harvested late or those with low moisture concentrations often present packing problems. In such cases, air pockets trapped within the forage mass are more difficult to exclude because the dry stems hinder packing. Yeast and mold growth in the air pockets can lead to increased temperatures and poorer fermentation. Therefore, forages should be harvested for silage at recommended moisture concentrations and maturities (Table 1). Water should be added to high DM silages ( $>55 \%)$ to provide adequate moisture for the bacteria and to improve packing.

\section{Chop Length and Processing}

Precision-chop forage harvesters with sharp knives should be used to achieve a chop length of $3 / 8$ inch for unprocessed corn silage and $3 / 4$ inch for processed corn silage. Processing helps ensure proper utilization of the energy in the corn kernel.

Processing is advised for flint corn or hybrids with high dry-down rates, high stay-green rankings, high vitreousness, or hard kernels. Processing can increase starch digestibility by about 5 percentage units, which can lead to over $1 \mathrm{lb}$ of extra milk produced per day. The roll clearance of processors should be set to $1-3$ $\mathrm{mm}$ because inadequate processing may not sufficiently damage kernels and release the energy-dense starch, whereas excessive processing can reduce fiber digestibility and predispose cows to acidosis. Processing forage sorghum hybrids before ensiling has not shown consistent benefits in research trials.

\section{Packing Density}

Silage shrinkage (DM losses) increases as packing density decreases, and poor packing density can also reduce the effectiveness of silage inoculants. A target packing density of $15 \mathrm{lb}$ of DM per $\mathrm{ft}^{3}(43 \mathrm{lb}$ of fresh forage per $\mathrm{ft}^{3}$ if silage is $35 \% \mathrm{DM}$ ) is required to minimize shrinkage. Kansas State University research reported that the optimum packing density can be achieved by aiming for a packing time of 1-4 minutes per ton and using delivery rates of about 30 tons/hour (wet weight). Delivery rates of over 60 tons/hour will lead to packing times less than 1 minute/ton, which can reduce packing density. High delivery rates that leave unpacked silage overnight should be avoided. A spreadsheet for properly managing bunker filling is available at www.uwex.edu/ces/crops/uwforage/storage.htm.

\section{Temperature}

The optimal internal temperature during fermentation is below $100^{\circ} \mathrm{F}$. Higher temperatures often result in poorer-quality silage. Temperatures above $100^{\circ} \mathrm{F}$ could reduce the fermentation quality, enhance protein degradation, and reduce the rapid $\mathrm{pH}$ decline necessary for an efficient fermentation. Excessively heated or heat-damaged silages have a brown to dark brown color with a tobacco-type smell. Part of the protein in "heat-damaged" silages is complexed with carbohydrates and is less digestible. The concentration of heat-damaged protein depends on both the temperature and the length of time the temperature is elevated. "Heat-damaged" silage may be palatable, but part of the protein and some of the energy it contains will be unavailable to livestock.

\section{Air Exposure}

Minimizing air (oxygen) infiltration during ensiling is essential for making good quality silage. The presence of air in the forage mass after harvest allows the respiration process to continue, and this depletes sugars essential for the fermentation. Air exposure during storage leads to yeast and mold growth on and beneath exposed surfaces. Air exposure at feeding also results in rapid yeast and mold growth, heating, and reduced palatability. Bunkers and bags should be sealed on the day of harvest to prevent subsequent spoilage and quality losses. After sealing, bag and bunker plastic integrity should be examined frequently, and any holes or splits should be immediately sealed with proper waterproof silage tape. Tire sidewalls (that are touching) should be used to weigh down the plastic and exclude air from bunker or drive-over-pile silos.

After opening a silo, silage at the silo face should be fed within 24 to 48 hours. Higher temperatures during the summer increase aerobic spoilage and reduce bunk life of the silage. During feeding, silage should be covered or left tightly packed until fed, and at least 8-12 inches of the exposed surfaces should be removed daily. 


\section{Additives}

Many different additives can be used to improve silage fermentation or provide supplementary nutrients to cattle. Forages such as corn or sorghum usually do not need additives to improve the fermentation provided they are harvested at the correct maturity stage and properly ensiled. However additives are usually necessary to enhance the aerobic stability (bunk life) of such forages. Additives are also important for improving the fermentation and aerobic stability of forages that are difficult to ensile such as warm-season grasses and legumes.

\section{Carbohydrate Sources}

Molasses can be used to add fermentable sugars to forages low in sugars, such as warm-season grasses and legumes. Adding 40 to $100 \mathrm{lb}$ of molasses/ton of forage at ensiling can increase the fermentation rate by increasing organic acid production and lowering the $\mathrm{pH}$. Other high-energy ingredients, such as ground corn and citrus pulp, may be added to increase the dry matter concentration in wet, warm-season grasses or legumes, and they often increase the energy value of the silage. However, molasses and other sugar or high-energy sources should not be added to corn, sorghum, or cool-season grasses at ensiling because the excess sugar availability will likely stimulate the growth of yeasts and the incidence of spoilage.

\section{Bacterial Inoculants}

Forages naturally contain up to 100,000 lactic acid bacteria/gram of plant. However, various types are present, and their ability to efficiently ferment sugars into lactic acid and rapidly drop the $\mathrm{pH}$ is usually low. Therefore, adding commercially-available silage inoculants containing selected strains of homolactic bacteria that enhance acidity can improve the fermentation and minimize nutrient and DM losses. Ideal homolactic inoculants should supply at least 100,000 live bacteria/gram of silage. Beneficial effects of such inoculants are often more common in forages with low sugar and DM concentrations, such as legume and grass silages, than in corn silage.
One of the limitations of using homolactic inoculants is that they may not reduce the incidence of aerobic spoilage (heating) when the silo is opened. Heterolactic inoculants containing Lactobacillus buchneri bacteria enhance the production of the antifungal agent, acetic acid. Such inoculants are therefore usually effective at reducing the growth of yeasts and molds and increasing aerobic stability of the silage. 'Combo' inoculants, which contain both homolactic inoculants and heterolactic L. buchneri bacteria, aim to enhance both the fermentation process and aerobic stability. Recent studies have confirmed their effectiveness on corn silage and bermudagrass silage.

\section{Acids}

Propionic acid reduces molding, heating, and aerobic deterioration and is an effective forage preservation agent. Adding acids such as propionic, sulfuric, or formic acid decreases the $\mathrm{pH}$ rapidly and improves the preservation, but the corrosiveness of these acids has discouraged widespread use. Several buffered propionic acid additives are commercially available that are less corrosive than the pure acids.

\section{Enzymes}

Forages with marginal concentrations of sugars may benefit from addition of enzymes that can break down complex plant carbohydrates to simple sugars, which then can be fermented to lactic acid. Enzymes such as amylases, cellulases, and pectinases can break down starch, cellulose, and pectin, respectively, in the forages. Most commercially available enzymes are mixtures of several enzymes produced from Bacillus and Aspergillus organisms. Although adding enzymes to forages that are difficult to ensile holds promise, enzyme addition has not consistently improved the ensiling quality of forages in research trials.

\section{Nitrogen Sources}

Ammonia and urea are sources of nonprotein nitrogen used to increase the crude protein concentrations of corn, forage sorghum, and other silages that are low in protein. Adding 5 to $10 \mathrm{lb}$ of anhydrous ammonia/ton or 10 to $20 \mathrm{lb}$ of urea/ton can increase crude protein concentration by 3 to 7 
percentage units in the silage DM. Higher rates of ammonia application should not be applied to silage because of the risk of formation of a compound that is toxic to cattle, especially very young livestock. Ammonia also inhibits growth of molds, therefore, ammonia-treated silages are less prone to heating and have a longer bunk life. Ammonia can be added at the chopper, blower, or bagger depending on the situation. Major drawbacks of ammonia are its volatility and corrosiveness, which pose risks to operators handling this chemical.

\section{Storage Systems}

Silos used to store forage during ensiling include vertical tower silos, horizontal bunkers and drive-over piles, stacks on the ground, or long plastic bags. Round bales of silage can also be stored in bags, tubes, stacks of bales under plastic, or stretch-wrapped individually or in in-line tubes. Tower or upright silos have not been popular in Florida due to the high initial capital investment.

\section{Chopped Silage Storage Systems}

These systems require specialized equipment, including a forage chopper, wagons or trucks for hauling the forage, a silo, and tractors or other power units for the equipment. The cost of equipment for this system is considerable; so producers using chopped silage typically harvest 1,000 tons or more each year if they own the equipment or hire custom operators to harvest smaller quantities. Corn forage should be chopped to $3 / 8$ inches, or to $3 / 4$ inches if processed, and grasses should be chopped to about 3/4 inches. Chopping allows better packing and air exclusion from the forage mass, but excess chopping can reduce saliva production by animals consuming the silage and reduce the milk fat test due to less chewing of the smaller forage particles. The chopper knives and the shear bar of the harvester need to be sharp and properly adjusted to consistently achieve the desired length of chop.

Upright silos (top-unloading and bottom-unloading) benefit from vertical gravitational pressure that improves packing density, and they have less silage surface exposed to air. These silos are well suited for storing up to a few hundred tons of silage, and the initial capital costs may be returned by reduced silage DM losses over several years of use. Storage losses under $10 \%$ of DM harvested have been reported in some studies using upright silos.

Bunker, trench, drive-over-pile, and stack silos offer horizontal storage for chopped forage with less investment per ton of stored silage and are widely used for storing large quantities of silage. These silos usually have higher DM losses during storage and feeding than upright silos. Dry matter losses (shrinkage) as low as 15 to $25 \%$ are possible, but losses above $30 \%$ have been reported. Dry matter losses can be reduced by chopping finely, packing well, filling the silo rapidly, harvesting at the optimal plant moisture, making deep piles of silage, covering the surface with a plastic sheet and covering the sheet with touching tire sidewalls, and feeding at least 8 to12 inches/day from the exposed face. Horizontal bunker silos are best suited for corn and sorghum silages where large quantities are harvested in one cutting (Figure 1).

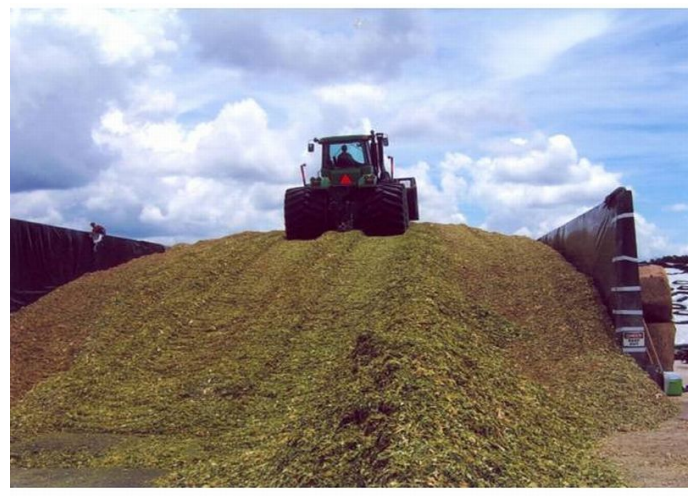

Figure 1. Packing silage in a bunker silo.

Silage in pressed-bag silos is made with bagging equipment that packs chopped silage into long plastic tubes (Figure 2). Bags from 100 feet to over 200 feet can store 0.75 to 2 tons/foot of length. The system is well suited for forages that need to be wilted for good preservation and is useful for storing smaller quantities of forages from different harvests or fields.

\section{Round-Bale Silage}

In recent years, round-bale silage has gained popularity for producers using smaller quantities of silage. Forage with higher moisture concentration than recommended for making hay (more than 18\% dry matter) can be baled and stored in plastic bags, 


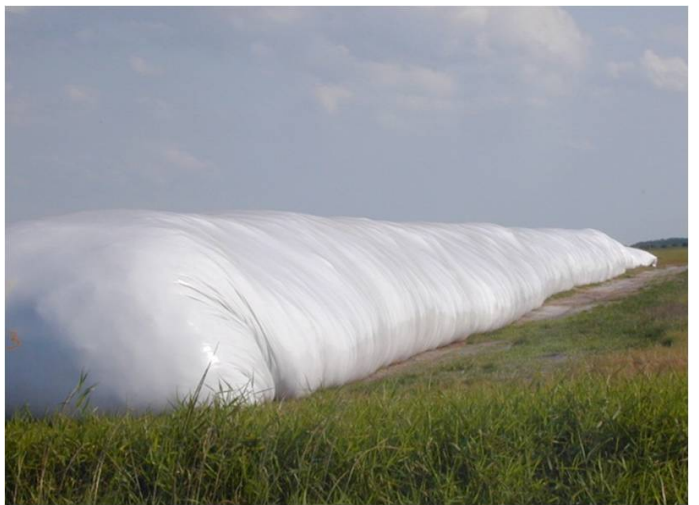

Figure 2. Silage stored in a pressed-bag.

tubes, or stacks without chopping. Alternatively, bales can be individually wrapped with stretched plastic (Figure 3), or several bales can be stretch wrapped in "in-line tubes" (Figure 4). Round bale silage storage systems require less capital investment than chopped-silage systems, especially for those producers who already have hay harvesting equipment. In the bag, stack, or traditional tube storage systems, more air is trapped in the enclosed bale, which often results in more shrinkage and nutrient losses. "Stretch-wrap" storage systems result in better air exclusion from the bale and are therefore more widely used. Among stretch-wrapped storage systems, in-line tubes are more popular than individual bales because they allow faster baling, use less labor, and use less plastic. However individual bales offer more flexibility because they can easily be moved.

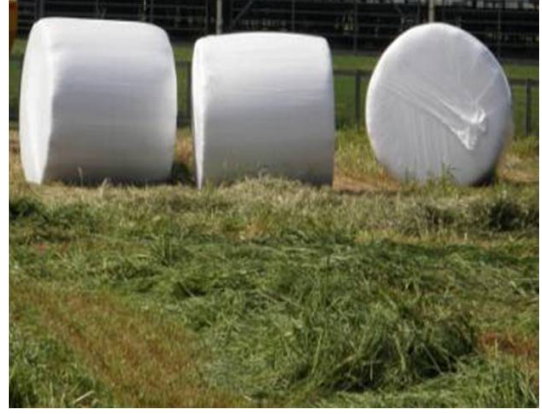

Figure 3. Individually wrapped silage bales.

It is important to wilt forages stored as round bale silage to approximately 45\% DM before baling. Wilting increases forage DM content in each bale and improves animal productivity. Wilting also decreases bale weights and reduces number of bales/acre, wrapping costs, and storage losses. Damage to plastic allows air to enter and cause spoilage. Such damage

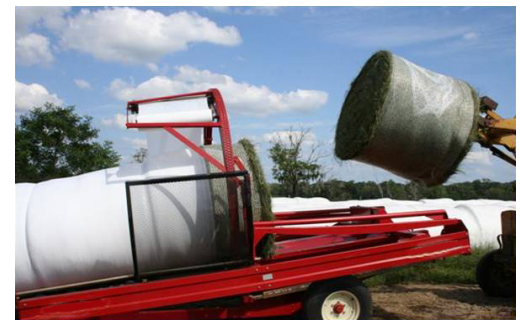

Figure 4. Round-bales of silage wrapped in an "in-line" tube.

may be due to poor plastic quality and punctures. Ultraviolet light from sunlight exposure can cause plastics to lose flexibility and break; therefore, selecting good-quality plastic is essential. Punctures of plastic from falling tree limbs, wildlife, cattle, rodents, and equipment can result in spoilage. Some of these failures can be avoided by proper handling and selection of storage areas. 
Table 1. Guidelines for harvesting and managing forages harvested as silage.

\begin{tabular}{|c|c|c|c|c|c|c|}
\hline \multirow[t]{2}{*}{ Crop } & \multicolumn{2}{|c|}{ Stage of Harvest } & \multirow{2}{*}{$\begin{array}{l}\text { Yield potential } \\
\text { tons } \\
\text { DM/acre/year }\end{array}$} & \multirow{2}{*}{$\begin{array}{l}\text { Dry } \\
\text { matter at } \\
\text { harvest, } \\
\%\end{array}$} & \multirow{2}{*}{$\begin{array}{l}\text { WSC } \\
\text { a } \% \\
\text { DM }\end{array}$} & \multirow{2}{*}{$\begin{array}{l}\text { Management } \\
\text { suggestions }\end{array}$} \\
\hline & $\begin{array}{c}\text { 1st } \\
\text { Harvest }\end{array}$ & $\begin{array}{c}\text { Additional } \\
\text { harvests }\end{array}$ & & & & \\
\hline \multicolumn{7}{|c|}{ Warm-season annuals } \\
\hline Corn & $\begin{array}{l}\text { Dry matter } \\
\text { content of } \\
30-35 \%\end{array}$ & -- & $4-8$ & $28-35$ & $10-20$ & Direct cut \\
\hline Forage sorghum & $\begin{array}{l}\text { Boot or } \\
\text { soft dough }\end{array}$ & -- & $\begin{array}{c}\text { 3-8 } \\
\text { /harvest }\end{array}$ & $20-35$ & $10-20$ & $\begin{array}{l}\text { Select varieties } \\
\text { with higher dry } \\
\text { matter at harvest } \\
(>30 \% \text { DM) }\end{array}$ \\
\hline $\begin{array}{l}\text { Sudan, } \\
\text { sorghum-sudan, } \\
\text { millet }\end{array}$ & $\begin{array}{l}36 " \text { height } \\
\text { to boot }\end{array}$ & $\begin{array}{c}36 " \text { height to } \\
\text { boot }\end{array}$ & $\begin{array}{c}2-4 \\
\text { /harvest }\end{array}$ & $15-30$ & $10-15$ & Wilt if $<28 \%$ DM \\
\hline Soybean & $\begin{array}{l}\text { Pre-pod to } \\
\text { bean fill, } \\
\text { before } \\
\text { leaf drop }\end{array}$ & -- & $1-3$ & $25-40$ & $2-4$ & Wilt if $<30 \% \mathrm{DM}$ \\
\hline Cowpea & $\begin{array}{l}\text { Pre-pod to } \\
\text { pea fill }\end{array}$ & -- & $1-3$ & $15-30$ & $5-8$ & Wilt if $<30 \% \mathrm{DM}$ \\
\hline \multicolumn{7}{|c|}{ Cool-season annuals } \\
\hline $\begin{array}{l}\text { Rye, oats, } \\
\text { wheat, triticale }\end{array}$ & $\begin{array}{l}\text { Boot to } \\
\text { soft dough }\end{array}$ & -- & $2-4$ & $20-30$ & $8-12$ & Wilt if $<25 \% \mathrm{DM}$ \\
\hline Ryegrass & $\begin{array}{l}\text { Boot to } \\
\text { heading }\end{array}$ & $\begin{array}{c}\text { Every } 30 \\
\text { days }\end{array}$ & $2-4$ & $15-30$ & $8-12$ & Wilt if $<25 \% \mathrm{DM}$ \\
\hline \multicolumn{7}{|c|}{ Warm-season perennials } \\
\hline $\begin{array}{l}\text { Bermudagrass, } \\
\text { stargrass }\end{array}$ & $\begin{array}{l}\text { Pre-head } \\
(12-15 " \\
\text { tall) } \\
\end{array}$ & $\begin{array}{c}\text { Every } 4-5 \\
\text { weeks }\end{array}$ & $6-10$ & $18-30$ & $2-4$ & Wilt if $<30 \% \mathrm{DM}$ \\
\hline Bahiagrass & Pre-head & $\begin{array}{c}\text { Every } 4-5 \\
\text { weeks }\end{array}$ & $3-5$ & $20-30$ & $<5$ & Wilt if $<30 \% \mathrm{DM}$ \\
\hline Limpograss & $\begin{array}{l}12-15^{\prime \prime} \\
\text { tall }\end{array}$ & $\begin{array}{c}\text { Every } 5-7 \\
\text { weeks }\end{array}$ & $4-8$ & $20-30$ & $<5$ & Wilt if $<30 \% \mathrm{DM}$ \\
\hline $\begin{array}{l}\text { Perennial } \\
\text { peanut }\end{array}$ & $8-12 "$ tall & $\begin{array}{c}\text { Every } 5-7 \\
\text { weeks }\end{array}$ & $2-4$ & $18-30$ & $1-4$ & Wilt if $<30 \% \mathrm{DM}$ \\
\hline \multicolumn{7}{|c|}{ Cool-season perennial } \\
\hline Alfalfa & $\begin{array}{l}\text { Bud to } \\
10 \% \\
\text { flower }\end{array}$ & $\begin{array}{l}\text { Bud to } 10 \% \\
\text { flower }\end{array}$ & $4-6$ & $22-35$ & $4-7$ & Wilt if $<30 \% \mathrm{DM}$ \\
\hline
\end{tabular}

